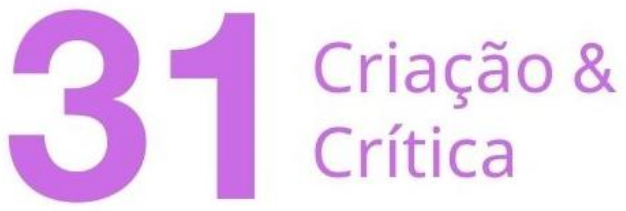

\section{GAL, A FATAL - O TROPICALISMO MUSICAL E O GESTO INTERPRETATIVO DE GAL COSTA}

Taissa Maia Amorim Cordeiro ${ }^{1}$

RESUMO: Este artigo apresenta um novo recorte dos fatos relacionados ao tropicalismo, a fim de refletir sobre o papel de Gal Costa na história desse movimento e sobre os sentidos de seu canto para a crítica musical brasileira. Faz-se isso por meio de uma pesquisa que foi empreendida em entrevistas da artista aos jornais de grande circulação da época, além de documentários e programas de televisão. Ao longo do artigo, a história oficial do tropicalismo e a tradição crítica que pensou o tema foram indagadas, com o objetivo de melhor compreender o lugar ocupado por Gal nos debates que envolvem esse movimento de vanguarda. Não só isso, reflete-se sobre conceitos como autoralidade, composição, a corporalidade empregada como discurso cênico, entre outros tópicos que residem nas interseções entre música e literatura.

Palavras-Chave: Música Popular Brasileira; Tropicalismo Musical; Gal Costa; Corporalidade; Autoralidade.

\section{GAL, A FATAL - MUSICAL TROPICALISM AND GAL COSTA'S CREATIVE GESTURE}

ABSTRACT: This article presents a new approach to facts related to tropicalism, in order to reflect on the role of Gal Costa in the history of this movement and on the meanings of her singing for a Brazilian music critic. This is done through a research in major newspaper for her interviews, as well as documentaries and television programs. Throughout the article, the official history of this avant-garde movement and the critical tradition that refers to the theme were investigated, with the aim of understanding the place occupied by Gal in debates involving musical tropicalism. Not only that, the article reflects on concepts such as authorality, composition, corporeality used as scenic discourse, among others that reside at the intersections between music and literature.

KeY-woRdS: Popular Brazilian Music; Musical Tropicalism; Gal Costa; Corporeality; Authorality.

\footnotetext{
Mestre em Comunicação e Cultura pela UFRJ, onde desenvolveu a pesquisa "Linda, feia e (des)aparecida: a mulher e os discursos sobre o tropicalismo musical". Possui pós-graduação Lato Sensu em Arte e Literatura pela PUC-Rio e graduação em Administração com ênfase em Entretenimento e Marketing pela ESPM-Rio. Professora, pesquisadora e produtora cultural. Contato: taissamac@hotmail.com
} 


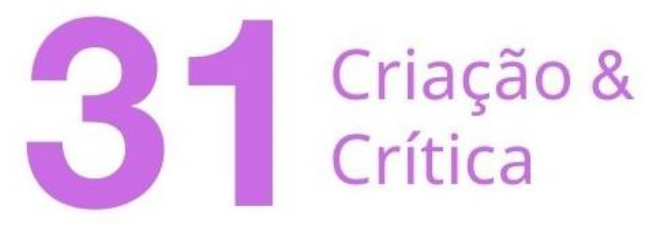

\section{Uma outra verdade tropical}

Seria o tropicalismo de Gal Costa uma leitura própria e autoral dessa estética de vanguarda? Conhecer a história clássica da música popular brasileira talvez nos leve a responder que não, pois o saber construído em torno desse movimento costuma priorizar as visões de Caetano Veloso e Gilberto Gil. No entanto, alguns dados fazem crer que há outra interpretação possível para os acontecimentos do final da década de 1960 e início da década de 1970. Sendo assim, este artigo apresenta um novo recorte dos fatos relacionados ao movimento tropicalista, a fim de refletir sobre o papel de Gal Costa na história do tema e sobre os sentidos de seu canto para a crítica musical brasileira.

Em primeiro lugar, é preciso retomar o contexto histórico em questão: de acordo com Coelho, no ano de 1968 a violência estava sendo corroborada na sociedade pela ditadura militar $^{2}$ e o campo cultural refletia isso de modo pujante. $O$ autor cita algumas ações violentas causadas pelo regime autoritário, como a morte do estudante secundarista Edson Luís, a prisão de 739 jovens no congresso da União Nacional dos Estudantes (UNE) e a fundação dos grupos armados de esquerda que não encontravam outra prática de luta contra o golpe. De um ponto de vista simbólico, as artes caminhavam na mesma direção (COELHO, 2010, p.166-170). Um exemplo aconteceu em setembro de 68, quando Caetano disputou a primeira eliminatória do III Festival Internacional da Canção (FIC) com É proibido proibir, sendo xingado de "bicha!" pela plateia. A recepção na segunda eliminatória foi mais brutal, resultando em seu famoso discurso direcionado à "juventude que dizia querer tomar o poder" ${ }^{3}$. Durante a fala de Caetano, Gil adentrou o palco e pegou um dos tomates que foram lançados. Num gesto ousado, mastigou parte do fruto e jogou o resto de volta, sem escapar, entretanto, de um pedaço de madeira que lhe cortou a canela e tirou sangue (CALADO, 2008, p.218-22).

Para Coelho, episódios como o descrito anteriormente denotam um acirramento entre o tropicalismo musical e o público que exigia deles determinado compromisso político (COELHO, 2010, p.164). Tal embate se explica a partir de um cenário que já vinha se engendrando desde o final dos anos de 1950. Foi nessa década que ganhou força o ideal nacional-desenvolvimentista, ou seja, a aposta na cultura nacional e popular como um veículo para erradicar o mal do subdesenvolvimento e atingir o patamar dos países de "Primeiro Mundo". Tratava-se de dar privilégio à arte no processo civilizatório (lbid., p.69). Logo, nos anos 60, esse foi o debate que pautou a ação cultural e que foi articulado, sobretudo, pelo Centro Popular de Cultura (CPC) ligado à UNE (GONÇALVES; HOLLANDA, 1982, p. 10). Com o início da ditadura militar, em 1964, o ente foi fechado e a lacuna que ele deixou abriu

\footnotetext{
${ }^{2}$ A ditadura militar no Brasil se inicia em 1964 e termina em 1985. Ocorreu durante a Guerra Fria, resultado de um golpe promovido pelas Forças Armadas que depôs o presidente eleito João Goulart. Como consequência imediata, a suspensão dos direitos políticos de opositores e a cassação de mandatos. Principalmente a partir de 1968, o Estado intensificou a censura, a vigilância e as prisões que envolviam torturas e desaparecimentos. Cf.: GASPARI, Elio. A Ditadura Envergonhada. São Paulo: Companhia das Letras, 2002.

3 "Mas é isso que é a juventude que diz que quer tomar o poder? (...) Eu quero dizer ao júri: me desclassifique. Eu não tenho nada a ver com isso. Gilberto Gil está comigo, para nós acabarmos com o festival e com toda a imbecilidade que reina no Brasil. Acabar com tudo isso de uma vez. Nós só entramos no festival pra isso. (...) Nós, eu e ele, tivemos coragem de entrar em todas as estruturas e sair de todas. E vocês? Se vocês forem em política como são em estética, estamos feitos!" (VELOSO, 1968, in: COELHO; COHN, 2008, p.168-9).
} 


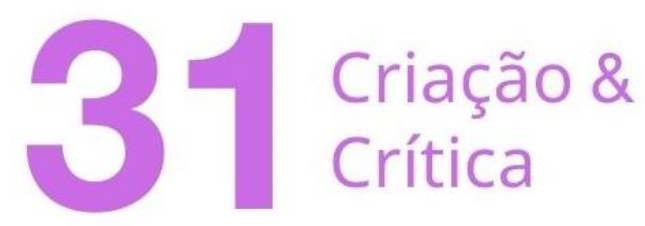

espaço para o surgimento de outros modos de resistência, que não reivindicavam a herança do nacional-desenvolvimentismo.

O tropicalismo musical foi o produto-síntese dos agenciamentos culturais que se distanciavam do CPC e da canção de protesto. Os novos agentes produziam artes plásticas, cinema, poesia e teatro, preocupando-se com a forma, com as múltiplas linguagens, com o conteúdo do cotidiano urbano, com a agressividade e a marginalidade. Gonçalves e Hollanda citam Hélio Oiticica como um nome relevante dessa corrente. Em obras como as desse artista plástico, a política era trabalhada de maneira distinta: o engajamento do espectador ganhava vida com a participação através de seus gestos, de seu corpo e de suas sensações (GONÇALVES; HOLLANDA, 1982, p.26-8). Porém, a tendência representada por Oiticica, Glauber Rocha (cinema) e Zé Celso (teatro), entre outros, não compactuava com a ideia de que a classe artística conduziria o desenvolvimento do país. Isso porque, conforme conta Zé Celso em depoimento à Hollanda, os que se afastavam do CPC não viam os estudantes como donos da verdade sobre o Brasil. Eles apontavam as contradições dessa elite intelectualizada, pois entendiam que a identidade nacional não podia ser expressa por uma via única. Não existia somente uma cultura hegemônica capaz de dialogar com o povo brasileiro, assim como não existia somente um povo brasileiro, mas corpos polifônicos que utilizavam erotismo e comportamento em sentidos desviantes e potencialmente resistentes (in: HOLLANDA, 2004, 701).

Segundo Coelho, no final dos anos 60 os tropicalistas da ala musical estreitaram laços com os tropicalistas envolvidos nas demais frentes artísticas. Isso ocorreu devido ao acirramento das tensões sociais que, como foi dito anteriormente, resultaram das ações diretas causadas pelo golpe militar. Porque pessoas como Hélio Oiticica e Glauber Rocha se valiam de inspirações marginais para travar disputas políticas num campo sensível, Caetano Veloso e Gilberto Gil também beberam dessa fonte (COELHO, 2010, p.166-170). A briga entre a dupla de baianos e o público hostil, tributário do nacional-desenvolvimentismo do CPC, que se desenrolou durante a apresentação de É proibido proibir, demonstra que eles não estavam mais dispostos a conciliar com as expectativas desse segmento ${ }^{4}$. O que se seguiu nos últimos meses de 68 foi o despontar de performances cada vez mais radicalizadas.

Nas vésperas do Natal daquele ano, enquanto gravava a série televisiva Divino Maravilhoso, Caetano cantou Boas festas com um revólver apontado para a cabeça. Ele fazia alusão a Assis Valente, o autor da música, um poeta baiano, negro e bissexual que se suicidou em 1958. O editor do programa usou todos os recursos disponíveis para que a arma não aparecesse em primeiro plano, já que uma cena forte como aquela agravaria o impasse em que se encontrava a TV Tupi: por causa de Divino Maravilhoso, cartas indignadas chegavam aos montes na emissora (CALADO, 2008, p.251). Nesse sentido, os tropicalistas também deixavam de conciliar com as necessidades de um mercado consumidor para o qual 0 movimento ainda significava uma espécie de moda irreverente. A proposta da vanguarda havia sido vista dessa maneira num primeiro momento, entre 1967 e o início de 1968, pois Caetano abraçou a ideia de difundi-la na indústria cultural de massa. Coelho acredita que o

\footnotetext{
${ }^{4}$ Tais disputas eram mais amenas em 1967. Quando Caetano, Gil e os Mutantes se apresentaram no III Festival da Música Popular Brasileira da TV Record, em outubro daquele ano, a audiência começou os vaiando, mas terminou aplaudindo. Na ocasião eles defenderam duas canções cujas apresentações são consideradas o momento inaugural do tropicalismo, Alegria, alegria e Domingo no Parque.
} 


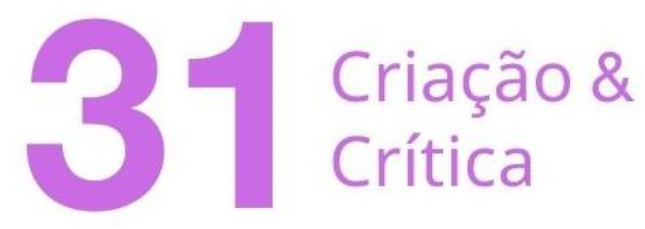

marco de tal postura se deu quando, em abril de 68, o compositor cantou na Discoteca do Chacrinha vestido com um camisolão estampado de bananas (2010, p.136-7). Contudo, à medida que o Brasil encarava as consequências do Ato Institucional nำ (Al5), surgia a demanda por mais subversão ${ }^{5}$.

Com o Al5 a perseguição aos artistas se fortaleceu e os líderes do tropicalismo musical foram tidos como o alvo, principalmente, desde um show realizado na boate Sucata, no Rio de Janeiro. A presença de uma bandeira de Oiticica no cenário, que trazia a frase "Seja marginal, seja herói", homenageando o bandido Cara de Cavalo, fez com que a temporada fosse cancelada. No dia 27 de dezembro, Caetano e Gil foram detidos em São Paulo, colocados num camburão e levados ao Rio. Passaram dois meses presos e mais cinco meses em prisão domiciliar. Exilaram-se em Londres, legando a tarefa da continuidade do movimento à Gal Costa. No dia 26 de julho de 1969, um dia antes de embarcar, Caetano deu a seguinte entrevista ao jornal Última Hora:

Sei que o movimento que a gente começou está influenciando meio mundo. Mais dia, menos dia, era inevitável que aqui também se começasse a utilizar uma linguagem nova. Isso demonstra que estávamos certos e o que fazíamos, aquela confusão toda, era um acontecimento natural no processo musical brasileiro. Quanto ao Tropicalismo, ainda não posso falar muita coisa. É claro que ele mantém raízes. O fato é que Gal Costa se tornou a mais importante cantora brasileira a partir dele e eu acho que isso já compensa. Se o Tropicalismo passou, eu não sei, mas acho que (...) ele continua, e do modo certo, com Gal (VELOSO, 1969, in.: CALADO, 2008, p.264).

\section{O tropicalismo segundo Gal Costa}

Desde que deixou a Bahia para morar no Rio de Janeiro, em 1965, a performance de Gal no palco apresentava uma nítida influência bossanovista ${ }^{6}$. É da seguinte forma que Juvenal Portela descreve a participação da cantora no I FIC de 67, numa reportagem publicada pelo Jornal do Brasil: "o canto de Gal Costa resume tristeza e timidez (...). Gal, que vi no I Festival Internacional da Canção, é uma moça que irradia ternura e que sugere quietude no seu jeito de posar e olhar (...)" (PORTELA, 1967, p.2). No entanto, ao longo de 1967 e

\footnotetext{
${ }^{5}$ Promulgado em dezembro de 1968, o Al5 foi, segundo Gaspari (2002, p.356), uma "reedição dos conceitos trazidos para o léxico político em 1964". Isso porque, dava-se nova tipificação legal para a censura, as cassações e perseguições, além do fechamento do Congresso Nacional e da suspenção do habeas corpus. Cf.: GASPARI, Elio. A Ditadura Envergonhada. São Paulo: Companhia das Letras, 2002.

${ }^{6}$ De acordo com Naves (2001), a bossa nova foi um estilo que se desenvolveu a partir de 1958 e que rompia com um tipo de sensibilidade comum na música popular brasileira, a do excesso. Considerando inadequado o repertório anterior a eles, como o samba-canção e os tangos abrasileirados, os representantes da bossa nova fizeram uma releitura do samba tradicional de modo a trocar os grandes arranjos de orquestra por conjuntos mais comedidos, de poucos instrumentos, e a voz potente e cênica por uma voz intimista. Cf.: NAVES, Santuza. Da bossa nova à Tropicália. Rio de Janeiro: Zahar, 2001.
} 


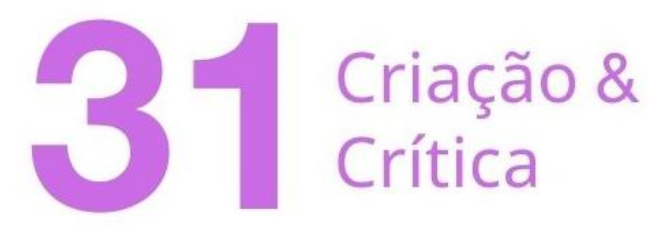

1968, ela foi se apropriando do ethos tropicalista circundante, algo que pode ser visto num depoimento concedido ao documentário O nome dela é Gal:

O momento da Tropicália para mim - onde aconteceu toda essa coisa nova que foi chamada de Tropicália - foi muito importante porque era um momento em que as coisas novas aconteciam com relação à música, com relação à linguagem, e eu estava envolvida com isso de uma forma ou de outra, por ser amiga de Caetano e de Gil, por gostar de música e por ter interesse numa carreira musical de cantora. Esse momento foi tão forte, tão impulsivo que me deu uma força interior. Então eu descobri muitas coisas novas nessa época, eu tô falando da Tropicália com relação ao meu trabalho, e na época teve também a coisa da Janis Joplin, quer dizer, tudo isso para mim me deu um pique muito forte para fazer uma coisa nova que começou com Divino Maravilhoso (...) (COSTA, in: FERREIRA, 2017).

Nota-se que Gal se coloca ativa diante das transformações do período, ou seja, como alguém que foi capaz de inovar os rumos da própria carreira a partir das informações culturais que recebia. Tal análise subverte o papel comumente atribuído a ela na história clássica do tropicalismo. Um papel que não escapa daquilo que Cixous observa sobre os discursos em geral: neles há um binômio constante, o da atividade/passividade, no qual a mulher está mais alinhada com o polo passivo (CIXOUS, 1988, p.287-8). O mesmo ocorre com os discursos que procuram narrar os fatos históricos por trás do movimento tropicalista. Cita-se como exemplo um trecho retirado das memórias de Caetano Veloso, em que o compositor se recorda dos integrantes da vanguarda que liderou: "mas quem éramos 'nós'? Gil, é claro, e eu, que, naturalmente, contaríamos com a participação de Gal para servir de intérprete e musa inspiradora" (VELOSO, 1997, p.98).

A afirmação de Veloso entra em conflito com a questão da autoralidade no canto de Gal Costa que se pretende discutir aqui. Quando utiliza a expressão "servir" de intérprete, o baiano parece enxergar nela apenas um receptáculo para suas canções. A imagem da musa não é menos redutora. Para Perrot, às mulheres é entregue a alcunha de "musa inspiradora" porque seu poder de invenção é negado (2007, p.96). Volta-se, portanto, à pergunta que abre este artigo: seria o tropicalismo de Gal Costa uma leitura autoral que a artista criou com base nas premissas dessa vanguarda estética? A relevância do debate reside no fato de que, ainda de acordo com Perrot, a capacidade ativa da criação é entregue aos homens. No que diz respeito à música, elas podem ser as intérpretes, as musas, mas não compor (PERROT, 2007, p.96).

Desse modo, chama-se a atenção do leitor para a "coisa nova" que Gal Costa empreendeu a partir de sua defesa da música Divino Maravilhoso no IV Festival de MPB da Record, em novembro de 1968. Num texto escrito em 2005, ela revela que escolheu essa composição de Caetano e Gil e que propôs uma performance "explosiva". Assim, orientou o arranjo com o objetivo de se livrar da menina que "cantava a bossa nova quietinha num banquinho" (COSTA, 2005). Percebe-se que, a despeito da associação da mulher à passividade, Gal formulou sua persona tropicalista num processo de reelaboração ativa da 


\section{Criação \&}

canção original. Em conformidade com o que atesta Diniz acerca de João Gilberto, pode-se dizer que ela também realizou o feito de ser uma recriadora "de canções que se tornam objetos rasurados pelo seu recorte vocal" (DINIZ, 2003, p.107).

Respondendo à pergunta inicial, afirma-se que a voz de Gal Costa carregava sim uma assinatura do movimento tropicalista. Longe da mulher passiva que recebe composições masculinas e as executa, ela era dotada de um canto capaz de reler a música, o texto e todos os discursos culturais do final dos anos 60 (Ibid., p.109). Afinal, como define Machado, o gesto interpretativo produz um sentido que extrapola os limites da canção original. Ou seja, o intérprete cria significados que só existem pela presença da voz ao equilibrar ou desequilibrar letra e melodia, escolher a emissão, o timbre, a articulação rítmica e a capacidade emotiva (MACHADO, 2012, p.17; p.44-54). Sendo assim, entendendo a apresentação de Divino Maravilhoso, no final de 1968, como o princípio do agenciamento dessa cantora em torno da estética tropicalista, pode-se considerar aquilo que veio após a data como o tropicalismo segundo Gal Costa.

Em abril de 1969 ela fez um show na boate Sucata e o Jornal do Brasil declarou: "Gal nunca dá os mesmos gritos nas mesmas horas. Tudo é espontâneo, sai naturalmente. É decorrência do seu amadurecimento e de sua maior confiança" (Jornal do Brasil, 1969, p.3). Segundo o jornal, o que se destacava no espetáculo eram os seus improvisos e o fato dela "criar interpretações inéditas", indícios de que o canto de Gal reafirmava o caráter de reelaboração do qual falam Diniz (2003) e Machado (2012). Sobre uma outra montagem que a artista e Jards Macalé levaram para o Teatro Oficina, em novembro daquele ano, o Diário da Noite diz ter sido uma "aparição do consumo" promovida pela empresa Tropicarte (VIANA, 1969, p.6). Capinam, Paulinho da Viola, Gal e Macalé foram sócios nessa iniciativa, que tinha o objetivo de gerir suas carreiras, mas sem pretensão de lucro. O aspecto experimentalista da Tropicarte se refletia na relação que eles estabeleceram com a dimensão econômica do cenário musical, já que o retorno financeiro era pouco expressivo (TERRON, 2014).

Uma prova relevante do protagonismo que Gal Costa assumiu no movimento tropicalista após 1968 - e de que essa vanguarda não teve fim com o exílio de Caetano e Gil - é o comentário que ela fez ao Diário da Noite sobre seu disco Gal, lançado no segundo semestre de 69: "desenvolvo um trabalho colocado dentro da proposta descontraída do tropicalismo e acentuado no meu último disco" (COSTA, in: VIANA, 1969, p.6). Por sua vez, o Jornal do Brasil publicou a seguinte entrevista em que a artista fala sobre o show no Teatro Oficina:

Sou aquilo que o público vê: uma cabeluda agressiva no palco. E terna também. (...) Já mudei muito do outro show [na boate Sucata] para este. Inclusive em matéria de expressão corporal. Vou descobrindo as coisas com o tempo e mudando. Já estou dançando diferente no palco. Diante do outro espetáculo, este é o mais forte, mas também mais livre, descontraído, sem nenhuma marcação rígida. Faço tudo o que quero, na hora e dia que quero. Tudo está de acordo com a minha maneira de cantar, mais livre ainda. Há um roteiro, um começo e um fim. Mas durante, nem a gente sabe o que vai acontecer. (...) Sei que sou importante na música brasileira, por várias razões. Surgi num determinado momento, meu jeito de cantar é diferente, minha 


\section{Criação \&}

aparência é diferente, minhas roupas e meu cabelo são diferentes. Sou a única cantora brasileira assim. Mas não é só isso. Sempre recusei a apatia e a passividade. Tenho consciência de participar de um movimento cultural. $E$ há um processo interior" (COSTA, in: BARBOSA, 1969, p.8).

Depois da temporada com Macalé no Teatro Oficina, Gal retornou à boate Sucata no Rio de Janeiro. Em maio de 1970, preparou uma nova incursão no palco com os sócios da Tropicarte, sem Paulinho da Viola, e com a colaboração de Hélio Oiticica. Aqui fica evidente que, assim como Caetano e Gil, ela estava buscando cada vez mais se associar aos tropicalistas das demais frentes. Capinam, seu parceiro na empresa, atuava como poeta e Oiticica, como já foi visto, era artista plástico. Não só isso, Gal cumpria com a seguinte definição de Duarte a respeito do movimento:

Tudo no Tropicalismo era trabalho estético e posicionamento cultural, o que situava programaticamente a música em um contexto amplo no Brasil. Envolvia as outras formas de arte, como teatro, artes plásticas e cinema (DUARTE, 2018, p.107).

Dessa maneira, é importante observar que as estratégias praticadas pela cantora se assemelhavam àquilo que o pensamento crítico do tema define sobre o tropicalismo em geral. Isso colabora com a resposta para nossa pergunta: se Gal Costa foi autora de uma versão própria dessa estética, não apenas reprodutora daquilo que Caetano e Gil criaram, então sua assinatura também passava pelo intercâmbio com as outras áreas da arte brasileira. Entretanto, mais do que os líderes baianos foram capazes de realizar, dada a repentina e forçada saída do país, ela pôde se aprofundar na confluência em torno da cultura marginal que marcou todos os tropicalistas a partir do fim de 1968 (COELHO, 2010, p.170).

O tropicalismo segundo Gal Costa atingiu seu ápice com a estreia, em outubro de 1971, do espetáculo Fatal. Nessa empreitada, ela reuniu uma série de elementos característicos do movimento, incluindo o recente aceno à cultura marginal e à radicalização. Contente afirma que esse foi o ponto máximo do papel político exercido por Gal contra a ditadura militar, resultando em um show que declarava publicamente a sua dor (2021, p.60). Jardim remonta a cena presenciada pelo público de Fatale, depois, fala sobre a capa do disco ao vivo, que leva o mesmo nome:

Gal era muito jovem, estava com 26 anos, magra e muito atraente. Usava um figurino que ela própria inventara, com a ajuda da figurinista Silvia Sangirardi: uma espécie de corpete, que deixava parte do corpo descoberto, uma saia longa escura, com a cintura baixa, e, na segunda parte do show, pintava a testa com uma maquiagem dourada, como uma tiara. Não era novata em shows nem em discos, e tinha sido capa da primeira edição brasileira da revista Rolling Stone. (...) A capa [do disco ao vivo] (...) traz fotos do show e suas cores mais marcantes vermelho, amarelo e o dourado da maquiagem. As palavras "Fa-tal", 


\section{Criação \&}

retirada de um poema de Waly [Salomão], e "Violeto", usadas no cenário, aparecem em destaque. O design do disco, assim como a ambientação do espetáculo, tem uma disciplina formal que revela o contato com as tendências construtivas da arte brasileira daquele período, especialmente com os trabalhos de Hélio Oiticica (JARDIM, 2017, p.63).

De acordo com Machado, os álbuns lançados pela cantora após 1968 mesclam "o gesto vocal bossanovista com a estridência tropicalista" (2012, p.39). Nesse sentido, Gal efetuava uma operação típica dessa vanguarda, a retomada da linha evolutiva da música popular brasileira, que foi nomeada pela primeira vez numa famosa frase de Caetano ${ }^{7}$. Em 1966, o compositor pensava que, em face dos acontecimentos gerados no campo cultural a partir do golpe militar, a única saída seria a tal retomada. Contudo, sua ideia não era nostálgica, pois o retorno serviria para que alguns elementos fossem resgatados e reinterpretados à luz das novidades musicais que ocorriam no mundo todo. Para ele, João Gillberto havia feito o mesmo com relação à bossa nova. Ou seja, apropriou-se do que tinha de mais moderno para renovar a tradição (VELOSO, 1966 in.: GONÇALVES; HOLLANDA, 1982, p.55).

Quando Gal Costa concebeu Fatal, o estilo de João Gilberto já havia sido incorporado à tradição da canção popular. Sendo assim, deixando-se influenciar por essa tradição e criando um espetáculo tropicalista, ela estava retomando a linha evolutiva. Jardim (2017) ressalta o fato de parte do corpo dela estar descoberto em Fatal. A sensualidade foi utilizada pela cantora como um denotativo de intensidade e feminilidade, além de um artifício convidativo para que o ouvinte se integrasse à performance. Quase como numa obra participativa, como as de Oiticica, Gal se comunicava com o público num ato cênico erotizado, escondendo e revelando seu corpo, no intuito de envolver a audiência com um jogo de sedução. Em síntese, o discurso tropicalista de Gal foi construído com base no corpo e na voz, conforme aponta Noleto (2014).

Machado analisa a faixa Falsa Baiana, extraída do disco Gal Fatal a Todo Vapor (1971), gravação ao vivo do espetáculo. A autora fornece alguns aspectos da retomada da linha evolutiva operada por Gal Costa. São eles, a improvisação, a passionalização, a leveza, a feminilidade e a sensualidade (MACHADO, 2012, p.97-108). É importante frisar que as informações trazidas pela intérprete não estavam no projeto originário do compositor Geraldo Pereira, logo, o canto e o corpo dela eram agentes que possuíam um valor semiótico. Ou seja, produziam novos signos, significados e representações. Em Falsa Baiana, Gal faz alusão à bossa nova, vocalizando um tema que João Gilberto cantou na introdução de Meditação. Não

\footnotetext{
7"Só a retomada da linha evolutiva pode nos dar organicidade para selecionar e ter um julgamento de criação. Dizer que samba só se faz com frigideira, tamborim e um violão sem sétimas e nonas não resolve o problema. Paulinho da Viola me falou há alguns dias da sua necessidade de incluir contrabaixo e bateria em seus discos. Tenho certeza que se puder levar essa necessidade ao fato, ele terá contrabaixo e fará samba. Aliás, João Gilberto é exatamente o momento em que isto aconteceu: a informação da modernidade musical utilizada na recriação, na renovação, no dar um passo à frente da música popular brasileira. Creio mesmo que a retomada da tradição da música popular brasileira deverá ser feita na medida em que João Gilberto fez. Apesar de artistas como Edu Lobo, Chico Buarque, Gilberto Gil, Maria Bethânia, Maria da Graça (que pouca gente conhece) sugerirem esta retomada, em nenhum deles ela chega a ser inteira, integral" (in: GONÇALVES; HOLLANDA, 1982, p.55).
} 


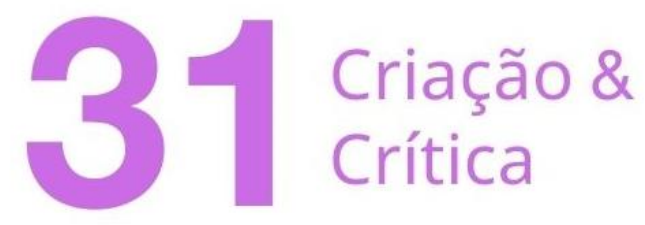

só isso, o tributo ao estilo também aparece porque ela mesma se acompanha no violão, dispensando outros instrumentos no arranjo (Ibid.).

Certamente, o tropicalismo que Gal Costa criou em cima da herança popular, inclusive da bossa nova, dialogava com o descobrimento do potencial estético e político do corpo. Relembrando o depoimento de Zé Celso à Hollanda, o diretor diz que não seria mais com a literatura e com as letras que se pensaria criticamente a cultura brasileira, pois os tropicalistas estavam falando uma linguagem corporal (in: HOLLANDA, 2004, 70-1). E isso se relaciona com a seguinte consideração de Duarte a respeito do movimento:

O tropicalismo necessitou (...) descobrir outras formas de apresentar (...) a presença em seus shows. "Caetano trouxe para o palco da praça e para a praça do palco o próprio corpo", constatou Silviano Santiago (...). Enquanto o corpo do cantor bossa-novista gostaria quase de desaparecer no espírito da canção, o que explica seu decoro nas vestimentas, o corpo do cantor tropicalista assume a sua presença mundana no palco, e daí advém o atrevimento de suas roupas (DUARTE, 2018, p.107).

Apesar do trecho anterior se referir a Caetano, constata-se o mesmo sobre Gal Costa. Pode-se dizer que ela borrou os limites entre o sujeito da vida privada e a persona artística, resgatando a bossa nova e adicionando um componente ousado. Conforme afirma Duarte, "o corpo do cantor bossa-novista gostaria quase de desaparecer" (Op.cit), entretanto, a leitura de Gal faz da presença da corporalidade um núcleo produtor de discursos. Dessa forma, ela promove nas canções originais uma rasura que remete à estética da bossa nova. Mas o completo entendimento dessa rasura requer uma atenção especial para o corpo e o figurino, elementos que são parte da obra reelaborada. Basta pensar na descrição que Jardim (Op.cit.) faz de Fatal: a nudez, as roupas, a maquiagem, além de outros itens cênicos, pertencem a um todo inédito; a uma nova versão em cima daquela concebida pelo primeiro compositor.

Quanto a "assumir a sua presença mundana no palco", há uma entrevista de 1970 em que Gal Costa diz: "a roupa tem que estar em função do que vou cantar, mas tem que estar de acordo com o meu dia. (...) A imagem é real, porque eu sou assim mesmo; em casa ou em público eu ando da mesma maneira" (COSTA, 1970, p.5). Daí se determina mais um valor dado à corporalidade e ao figurino, a saber, a capacidade que esses componentes tinham de transportar a cena contra cultural, vivida cotidianamente pelos jovens daquela década, para o show. Recordando o fim dos anos 60 e o início dos 70, em recente depoimento ao Programa do Bial, na TV Globo, a cantora afirma: "eu andava nas ruas com aquelas roupas tropicalistas, com aquele cabelo black power, e as pessoas me olhavam e achavam muito estranho" (COSTA, 2021). Nessa frase, Gal relaciona a estética do movimento à determinado jeito de se trajar, transformando as vestimentas numa espécie de elo entre a persona artística e a jovem que levava uma vida comum.

O cabelo inspirado no black power foi um símbolo da transição entre a Gal Costa bossanovista e a tropicalista. Cerca de uma década mais tarde, ela comentou o período da mudança ao Jornal do Brasil, atestando que, em 1968, era sexy de um jeito agressivo. Os que 


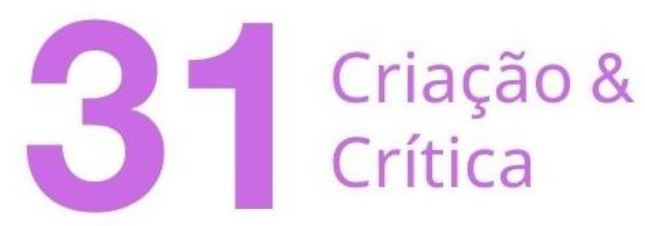

não faziam parte da movimentação contra cultural vigente a achavam feia e Gal relata ter sido ofendida com nomes como "macaca", "suja" e "piolhenta" (COSTA, 1979, p.1). A contextualização que Coelho (2010) faz daquele momento ajuda a explicar o fato dela ter atrelado a sensualidade à agressividade. Porque o Brasil se encontrava numa escalada violenta, a cantora precisou agenciar seu corpo a partir de uma chave combativa. Ela conta que era mais "gorda" e que emagreceu, adequando-se a um padrão de beleza acessível às pessoas no geral (Op.cit). Desse modo, nota-se que o caminho discursivo traçado por seu corpo foi sendo negociado com a indústria cultural. Não que a demanda comercial não estivesse presente antes, mas ela foi se intensificando.

Contudo, pretende-se ir além de uma análise superficial calcada na ideia de que a obra de arte, quando veiculada na indústria de massa, seria incapaz de apresentar focos de resistência política. Acredita-se que, mesmo em seus trabalhos mais lucrativos, Gal Costa não deixou de desafiar as conformações de gênero da sociedade patriarcal. Inclusive, o ato de penetrar o sistema com discursos potentes, recobertos por uma roupagem de fácil assimilação, firmou-se como um procedimento estético do tropicalismo. Portanto, a artista também o fez, utilizando o discurso erótico como isca para atrair o público jovem. Isso ocorreu, principalmente, desde Fatal e Noleto acredita que tal estratégia foi uma maneira de despertar o desejo dos fãs pelo ideal que ela oferecia de libertação sexual feminina. Nesse sentido, Gal dialogou com as pautas do feminismo de segunda onda (NOLETO, 2014, 65-70).

Um exemplo do que foi exposto anteriormente é a imagem que a cantora engendrou em torno do lançamento do disco Índia (1973). Noleto diz o seguinte sobre a capa desse trabalho:

\begin{abstract}
A fotografia da capa consistia num close up da região genital de Gal Costa encoberta por um biquíni vermelho e adornada por uma vestimenta indígena, confeccionada com palha e que era segurada pelas mãos da cantora. Esta foto e as fotos da contracapa, que exibem Gal Costa seminua com os seios à mostra, foram consideradas ofensivas aos "bons costumes" da sociedade brasileira da época e, por isso, o LP sofreu censura por parte do regime militar, que determinou que este álbum só poderia ser comercializado nas lojas se envolvido numa embalagem plástica opaca que encobrisse as fotografias feitas por Antonio Guerreiro (NOLETO, 2014, p.70).
\end{abstract}

Por meio desse trecho é possível refletir sobre como a nudez foi empregada tanto no sentido de chocar, despertando, assim, o interesse por parte do público, quanto no de confrontar a ditadura. Em suma, Gal Costa traduziu a contracultura e a cultura marginal de sua época utilizando um vocabulário erótico. Talvez essa tenha sido a sua maneira convidativa e irreverente de comunicar o tropicalismo. Do mesmo modo que Caetano entendeu, no início de 1968, que seria interessante levar a proposta ao programa do Chacrinha, a cantora tentou seduzir as massas com um corpo feminino. No entanto, ela introduzia uma feminilidade desviante daquela esperada pela sociedade. Mas não se engane, ambos estavam praticando manobras arriscadas e a negociação com a indústria cultural não visava um retorno financeiro despropositado. Especialmente naquele momento do Brasil, incomodava o fato de Caetano ser um homem que vestia um camisolão estampado de 


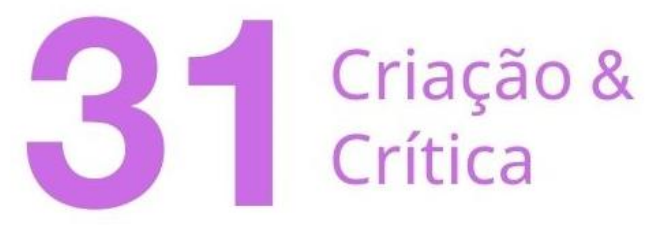

bananas, rebolando na TV, e de Gal ser uma mulher que pensava criticamente a herança da canção popular através de um corpo liberto sexualmente.

Gal Costa afirma que os shows Fatal (1972) e Índia (1973) possuíram forte acentuação no seu mergulho tropicalista, mas que decidiu mudar os rumos a partir do disco Cantar (1974) (COSTA, in: FERREIRA, 2017). Apesar de ser notório que ela nunca deixou de beber da fonte que nasceu com a vanguarda, há, aqui, uma aposta na cronologia demarcada pela própria cantora. Numa entrevista já citada, Gal diz que seu disco de 1969 estava contido dentro dessa proposta estética (COSTA, in: VIANA, 1969, p.6). Quanto ao ano anterior, sabese que a defesa de Divino Maravilhoso no IV Festival de MPB da Record foi a sua estreia tropicalista (COSTA, in: FERREIRA, 2017). Portanto, define-se o tropicalismo segundo Gal Costa como um movimento dentro do movimento, que começa no final de 1968, atinge seu ápice com Fatal (1972) e vai se desarticulando pouco a pouco até Cantar (1974). Assim, fica evidente que o tropicalismo continuou com ela e do modo certo, como disse Caetano.

\section{O binômio compositor/intérprete}

O recorte cronológico proposto anteriormente não costuma ser encontrado na história canônica do tropicalismo musical. Pelo contrário, os relatos mais difundidos são aqueles que priorizam a trajetória de Caetano Veloso e Gilberto Gil. Um exemplo disso é Tropicália: a história de uma revolução musical, escrito por Calado (2008). Nesse caso, a narrativa construída é costurada em torno da ascensão da dupla, que é estremecida pela queda durante a prisão e o exílio, mas que continua em sentido crescente após o obstáculo. O livro começa com eles presos, dando a deixa para que se explique como os artistas chegaram ali. Assim, passa por toda a gênese do movimento tropicalista, culminando no show da boate Sucata, em 1968, ponto máximo da tensão com o regime militar. Calado segue descrevendo o IV Festival de MPB da Record, quando Gal cantou Divino Maravilhoso, respeitando a ordem dos fatos, já que o show da Sucata aconteceu em outubro e o Festival, em novembro. Então, o autor retoma o cárcere e a viagem forçada à Inglaterra, terminando com o disco Araçá Azul, lançado em 1973 por Caetano, e com a herança tropicalista deixada às novas gerações (CALADO, 2008, passim).

Quase como se fosse a coadjuvante na história dos compositores, os passos de Gal Costa são submetidos aos deles. De acordo com Ribeiro, o historiador é um sujeito de seu tempo e que intervém para construir sentido. Ele o faz por meio da seleção, relação e valorização de determinados acontecimentos, dialogando com certas fontes e não com outras; organizando algumas vozes a fim de gerar um significado (RIBEIRO, 2005, p.107-9). Na posição de historiador, ou pelo menos daquele que produziu um livro que conta a história de um movimento musical, Calado engendrou uma narrativa que busca evidenciar o protagonismo de Caetano e Gil, secundarizando as demais jornadas. A despeito dessa escolha, tem-se a definição de Bay acerca do tropicalismo: um encontro de ideias e conhecimentos diferentes (2009, p.81). Logo, Gal não foi apena uma executora daquilo que foi planejado por Caetano e Gil, mas colaborou com o movimento de forma expressiva.

Afinal, se a artista possui uma assinatura própria dessa estética, por que a história registrou sua participação num lugar de menor relevância? Nesta última parte do artigo será evidenciada uma estratégia que parece ter contribuído com isso: a dissimetria de gênero causada pelo binômio compositor/intérprete (aqui, compositor está sendo usado como aquele 


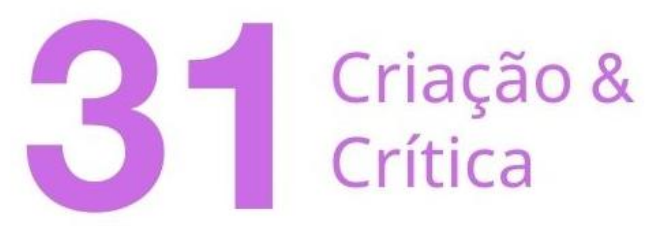

que cria letra e melodia). Defende-se que tal estratagema corroborou com a manutenção de um sistema machista nos discursos acerca do tropicalismo, pois o tema sempre foi pensado através de uma abordagem interdisciplinar, que abarcava, sobretudo, historiografia, crítica literária e crítica musical. É assim em, pelo menos, duas das obras fundantes da corrente de pesquisa que estuda o movimento: Impressões de Viagem, de Hollanda, publicada em 1980, e O balanço da bossa e outras bossas, coletânea de artigos escritos entre 1966 e 1970, organizada por Campos

Desde os primórdios dessa corrente de pesquisa, o texto é tratado como um componente central da canção. Hollanda abre o capítulo "O susto tropicalista na virada da década" trazendo o foco para a letra de Alegria, alegria, composta por Caetano. A autora enxerga nela a crítica direcionada à intelectualidade de esquerda e o flerte com os canais de massa (presentes nos versos "por entre fotos e nomes/ sem livros e sem fuzil/ sem fome, sem telefone/ no coração do Brasil/ ela nem sabe, até pensei/ em cantar na televisão) (HOLLANDA, 2004, p.62). Por sua vez, em $O$ balanço da bossa, as premissas da poesia concreta são aplicadas à música (NAVES, 2015, p.27-8). Sendo assim, percebe-se que nessas importantes referências do pensamento crítico brasileiro, a figura do letrista é destacada. Os livros, mais do que registros de seu tempo histórico, são eles mesmos objetos da história. Logo, consistem em artefatos constantemente resgatados quando se faz emergir o movimento tropicalista no contemporâneo.

No artigo "A explosão de Alegria, alegria", assinado por Campos em 1967, a canção de Caetano e Domingo no Parque, de Gil, tornam-se o marco propulsor da evolução na música popular brasileira. Ao lado deles, Rogério Duprat recebe os devidos louros pelo arranjo de Domingo no Parque que, para o autor, foi essencial no sentido de fazer dela uma música complexa (CAMPOS, 2012, p.154). Desse modo, melodia e o arranjo são somados à letra como componentes privilegiados. Mas, dentro de uma vanguarda central para a cultura brasileira, essas três atividades foram desempenhadas exclusivamente por homens. Todos os letristas, compositores e arranjadores tropicalistas são do gênero masculino. Enquanto as mulheres são as intérpretes de suas canções. Retoma-se as conceituações de Cixous (1988) e Perrot (2007), que apontam a comum assimilação do gênero feminino à passividade. Inclusive, na música isso se traduz como uma incapacidade de criar, restando, apenas, o ato de interpretar.

De forma bastante resumida, foram revistos os pilares que estruturam as análises de Impressões de Viagem e $O$ balanço da bossa, dois trabalhos seminais da pesquisa sobre o tropicalismo musical. No entanto, longe de defender que seus autores desejavam relegar Gal Costa a uma posição inferior, acredita-se que eles pensaram seu objeto em função de uma epistemologia ainda dominada por valores desiguais em termos de gênero. Seguindo a problematização que Rago faz da epistemologia tradicional (2019, p.373-4), isso quer dizer que eles iniciaram suas investigações baseados em operações científicas que valorizavam mais as práticas do homem, branco, heterossexual, "civilizado" e ocidental. Assim, a autoralidade da intérprete tropicalista ficou em segundo plano, pois o saber com o qual esses autores dialogavam atentava mais para a composição de letra e melodia, além do arranjo, que, por si só, já era um objeto de análise relativamente novo.

Não se pode esquecer que, segundo Naves, o campo cultural na virada da década de 50 para 60 passou a enxergar na canção popular um lócus dos debates estéticos e culturais. Com isso, os compositores se valeram da identidade de intelectuais, comentando 


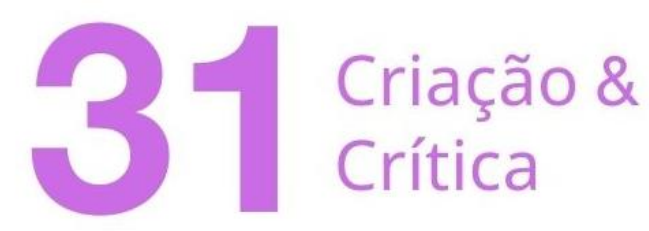

criticamente a própria obra e o contexto do país (NAVES, 2010, p.19-21). Todo esse protagonismo da figura do compositor ofuscava o papel da intérprete. Mas isso não significa que cantoras como Gal Costa não criaram ou que não refletiram criticamente o Brasil através de suas performances. A questão é que, ao contrário dos compositores tropicalistas, Gal emitia discursos por meio dos gestos vocais e corporais. Ela não compunha a letra e a melodia original, não escrevia a partitura dos arranjos, mas se apropriava de todas essas informações para gerar algo inovador ${ }^{8}$.

Por fim, sabe-se que os autores que iniciaram o campo do saber acerca do movimento responderam às necessidades despertadas pelo objeto em questão. Nas palavras de Favaretto:

O tropicalismo elaborou uma nova linguagem da canção, exigindo que se reformulassem os critérios de sua apreciação, até então determinados pelo enfoque da crítica literária. Pode-se dizer que o tropicalismo realizou no Brasil a autonomia da canção (...) [e que] efetuou a síntese de música e poesia (...). Por ser inseparavelmente musical e verbal, é difícil tanto compor a canção quanto analisá-la. (...) Além disso, a canção comporta o arranjo, o ritmo e a interpretação vocal (...) (FAVARETTO, 2007, p.32-3).

Por mais que não tenham se debruçado no canto ou na performance de Gal Costa, nem das outras mulheres tropicalistas ${ }^{9}$, eles abriram o caminho para que pesquisadores futuros o fizessem. Isso porque, de forma pioneira nos estudos da música popular, tematizaram o corpo e a postura cênica, além de terem introduzido um olhar atento para um sujeito Outro na ciência, na sociedade e na cultura. Da mesma forma que Zumthor (2005) desejava o desenvolvimento de um fazer científico que desse conta da riqueza da voz, para se apreender o tropicalismo em sua complexidade seria preciso o desenvolvimento de um fazer científico que também compreendesse a riqueza da corporalidade enquanto discurso. Pode-se dizer que o pontapé inicial foi dado com Hollanda (2004), Campos (2012), Favaretto (2007), entre outros autores que pensaram esse movimento de vanguarda nos anos 70 e 80. Nas mesmas águas que desembocaram estruturas dicotômicas, como os pares atividade/passividade e compositor/intérprete, iniciou-se um aceno capaz de contemplar as outras linguagens contidas na performance musical de cantoras mulheres, como Gal Costa.

\footnotetext{
${ }^{8}$ Aqui, refiro-me a maior parte do repertório de Gal, bem como, às músicas tradicionalmente atribuídas à estética tropicalista. Gal não compunha a letra e a melodia dessas canções, o que não quer dizer que ela não compôs nenhuma outra. A artista é autora de Love, try and Die, com Jards Macalé e Lanny Gordin, presente no disco Legal (1970), e Quando, com Caetano Veloso e Gilberto Gil, presente no disco Doces Bárbaros (1976). Curioso notar que ela não é reconhecida por esse ofício, nem quando se assume uma visão "ortodoxa" do que seria a composição e a autoralidade. Sobre o silenciamento das mulheres compositoras na música popular brasileira, cf.: MURGEL, Ana Carolina. Mulheres compositoras no Brasil dos séculos XIX e XX. Revista do Centro de Pesquisa e Formação SESC SP. São Paulo, n3, novembro de 2016.

${ }^{9}$ Sobre os questionamentos de gênero relativos à fortuna crítica que pesquisou o tropicalismo, levando em consideração as três mulheres que participaram ativamente do movimento, não só Gal Costa, mas também Nara Leão e Rita Lee, cf.: MAIA, Taissa. Linda, feia e (des)aparecida: a mulher e os discursos sobre o tropicalismo musical. Dissertação (Mestrado em Comunicação e Cultura) - Universidade Federal do Rio de Janeiro. Rio de Janeiro: 2021.
} 


\section{Criação \&}

\section{Referências bibliográficas}

BAY, Eduardo Kolody. Qualquer bobagem: uma história dos Mutantes. Dissertação (Mestrado em História) - Universidade de Brasília. Brasília: 2009.

CALADO, C. Tropicália: a história de uma revolução musical. São Paulo: Editora 34, 2008.

CIXOUS, Hélène. Sorties. In: Modern Criticism and Theory: a reader. Londres: Longman, 1988, pp.287-293.

COELHO, Frederico. Eu, brasileiro, confesso: cultura marginal no Brasil das décadas de 1960 e 1970. Rio de Janeiro: Civilização Brasileira, 2010.

CONTENTE, Renato. Não se assuste, pessoa! - as personas políticas de Gal Costa e Elis Regina na ditadura militar. São Paulo: Letra e Voz, 2021.

COSTA, Gal. [Entrevista concedida a] ALENCAR, Míriam. Gal Costa - sou uma mulher sensual, não sou radical. Jornal do Brasil. Rio de Janeiro, 7 de janeiro de 1979. Caderno B, p.1

COSTA, Gal. [Entrevista concedida a] BARBOSA, Rubens. Meu nome é Gal. Jornal do Brasil. Rio de Janeiro, 4 de dezembro de 1969. Caderno B, p.8.

COSTA, Gal. [Entrevista concedida a] MARIA, Léa. Meu nome é Gal e não vim fazer desfile. Jornal do Brasil. Rio de Janeiro, 29 de maio de 1970. Caderno B, p.5.

DUARTE, P. O Livro do Disco: Tropicália ou Panis et Circenses. Rio de Janeiro: Cobogó, 2018.

FAVARETTO, Celso. Tropicália alegoria, alegria. São Paulo: Ateliê Editorial, 2007.

JARDIM, Eduardo. Tudo em volta está deserto. Rio de Janeiro: Bazar do Tempo, 2017.

O NOME dela é Gal. Série documental. Direção de Dandara Ferreira. Brasil: 2017.

GONÇALVES, Marcos; HOLLANDA, Heloisa B. Cultura e participação nos anos 60. São Paulo: Editora Brasiliense, 1982.

HOLLANDA, Heloisa Buarque de. Impressões de viagem: CPC, vanguarda e desbunde. Rio de Janeiro: Aeroplano, 2004.

MACHADO, Regina. Da intenção ao gesto interpretativo: análise semiótica do canto popular brasileiro. Tese (Doutorado em Linguística) - Faculdade de Filosofia, Letras e Ciências Humanas da Universidade de São Paulo. São Paulo: 2012.

NAVES, S. Da Bossa Nova à Tropicália. Rio de Janeiro: Zahar, 2012.

NAVES, Santuza. Canção Popular no Brasil. Rio de Janeiro: Civilização Brasileira, 2010. 


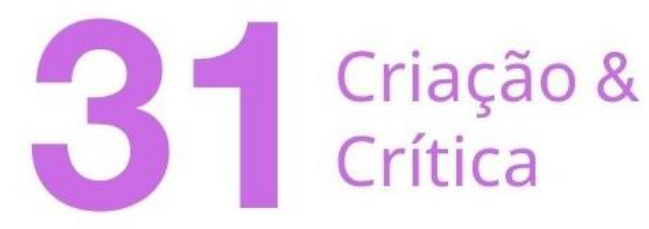

NOLETO, Rafael da Silva. Eu sou uma fruta gogóia, eu sou uma moça: Gal Costa e o Tropicalismo no feminino. In: Per musi. no 30, 2014.

PERROT, Michelle. Minha história das mulheres. São Paulo: Contexto, 2007.

PORTELA, Juvenal. Um disco de baianos para todos. Jornal do Brasil. Rio de Janeiro, 5 de julho de 1967. Caderno B, p.2.

RIBEIRO, Ana Paula Goulart. A mídia e o lugar da história. In: HERSCHMANN, Micael; PEREIRA, Carlos A. (orgs). Mídia, Memória e Celebridades. Rio de Janeiro: E-Papers, 2005. P.105-129.

TERRON, Paulo. Ocupação Jards Macalé - Revendo amigos. Itaú Cultural. 2014. Disponível em: < https://www.itaucultural.org.br/ocupacao/jards-macale/revendo-amigos/>. Acesso em: 22 de março de 2021.

TV Globo. Conversa com Bial: Gal Costa. 19 de fevereiro de 2021. (43min).

VELOSO, Caetano. Verdade Tropical. São Paulo: Companhia das Letras, 1997.

VIANA, Hilton. Show da Gal. Diário da Noite. São Paulo, 28 de novembro de 1969. Segundo Caderno, p.6.

COSTA, Gal. [Entrevista concedida a] MARIA, Léa. Meu nome é Gal e não vim fazer desfile. Jornal do Brasil. Rio de Janeiro, 29 de maio de 1970. Caderno B, p.5.

DUARTE, P. O Livro do Disco: Tropicália ou Panis et Circenses. Rio de Janeiro: Cobogó, 2018.

FAVARETTO, Celso. Tropicália alegoria, alegria. São Paulo: Ateliê Editorial, 2007.

JARDIM, Eduardo. Tudo em volta está deserto. Rio de Janeiro: Bazar do Tempo, 2017.

O NOME dela é Gal. Série documental. Direção de Dandara Ferreira. Brasil: 2017.

GONÇALVES, Marcos; HOLLANDA, Heloisa B. Cultura e participação nos anos 60. São Paulo: Editora Brasiliense, 1982.

HOLLANDA, Heloisa Buarque de. Impressões de viagem: CPC, vanguarda e desbunde. Rio de Janeiro: Aeroplano, 2004.

MACHADO, Regina. Da intenção ao gesto interpretativo: análise semiótica do canto popular brasileiro. Tese (Doutorado em Linguística) - Faculdade de Filosofia, Letras e Ciências Humanas da Universidade de São Paulo. São Paulo: 2012.

NAVES, S. Da Bossa Nova à Tropicália. Rio de Janeiro: Zahar, 2012.

NAVES, Santuza. Canção Popular no Brasil. Rio de Janeiro: Civilização Brasileira, 2010. 


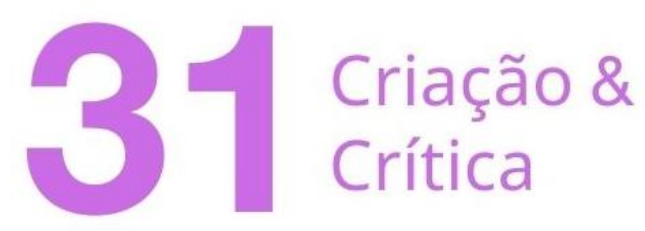

NOLETO, Rafael da Silva. Eu sou uma fruta gogóia, eu sou uma moça: Gal Costa e o Tropicalismo no feminino. In: Per musi. n 30, 2014.

PERROT, Michelle. Minha história das mulheres. São Paulo: Contexto, 2007.

PORTELA, Juvenal. Um disco de baianos para todos. Jornal do Brasil. Rio de Janeiro, 5 de julho de 1967. Caderno B, p.2.

RIBEIRO, Ana Paula Goulart. A mídia e o lugar da história. In: HERSCHMANN, Micael; PEREIRA, Carlos A. (orgs). Mídia, Memória e Celebridades. Rio de Janeiro: E-Papers, 2005. P.105-129.

TERRON, Paulo. Ocupação Jards Macalé - Revendo amigos. Itaú Cultural. 2014. Disponível em: < https://www.itaucultural.org.br/ocupacao/jards-macale/revendo-amigos/>. Acesso em: 22 de março de 2021.

TV Globo. Conversa com Bial: Gal Costa. 19 de fevereiro de 2021. (43min).

VELOSO, Caetano. Verdade Tropical. São Paulo: Companhia das Letras, 1997.

VIANA, Hilton. Show da Gal. Diário da Noite. São Paulo, 28 de novembro de 1969. Segundo Caderno, p.6.

ZUMTHOR, Paul. Escritura e nomadismo. São Paulo: Ateliê Editorial, 2005.

Recebido em: 30/08/2021

Aceito em: 29/10/2021

Referência eletrônica: CORDEIRO, Taissa Maia Amorim. et al. Gal, a fatal - o tropicalismo musical e o gesto interpretativo de Gal Costa. Criação \& Crítica, n. 31, p., dez. 2021. Disponível em: <http://revistas.usp.br/criacaoecritica>. Acesso em: dd mm. aaaa. 